ESJ Social Sciences

\title{
Drivers of Public Health Expenditure in Kenya: Do Structural Breaks Matter?
}

\author{
Cyprian Amutabi
}

School of Economics, University of Nairobi, Kenya

Doi:10.19044/esj.2021.v17n23p143

Submitted: 22 January 2021

Accepted: 22 June 2021

Published: 31 July 2021
Copyright 2021 Author(s)

Under Creative Commons BY-NC-ND

4.0 OPEN ACCESS

Cite As:

Amutabi C. (2021). Drivers of Public Health Expenditure in Kenya: Do Structural Breaks Matter?. European Scientific Journal, ESJ, 17(23), 143.

https://doi.org/10.19044/esj.2021.v17n23p143

\section{Abstract}

Health forms the basic foundation of the quality of human life, which is an ultimate ingredient towards the productivity and efficiency of an economy. The rapid growth of health expenditure has emerged as an enormous concern for many households and governments globally. This study used timeseries data for the period 1985-2018 in unearthing the drivers of healthcare expenditure in Kenya, with a central focus on the role of health shocks. The study also sought to assess whether structural breaks mattered in a healthcare expenditure model. A public healthcare expenditure model was estimated using the Autoregressive Distributed Lag (ARDL) model. The findings revealed the presence of a long-run relationship between public health expenditure and its determinants in Kenya. Population growth rate and $\mathrm{CO}_{2}$ emissions (proxy to respiratory illnesses) were found to significantly and positively determine public health expenditure in the short run. This impact was insignificant in the long run. Similarly, GDP per capita and the number of HIV/AIDs infections positively and significantly determined public health expenditure in the long run. A key finding of this study highlighted the importance of testing for structural breaks in analyzing a time-series healthcare expenditure model. Previously, this is something that has been largely omitted in the Kenyan healthcare context. The structural break dummy variables significantly determined public health expenditure and, therefore, their incorporation in the model yielded a more accurate forecast with better econometric estimates. The findings will be useful in informing the government's health budgetary allocation as well as the design of appropriate 
shock mitigation policies. This is paramount for the country in achieving not only Universal Health Coverage but also high-quality medical care to its citizens as envisioned in the 'Big Four Agenda' government priorities.

Keywords: Public health expenditure, structural breaks, ARDL model, Kenya

\section{Introduction}

The health financing system in many African countries is generally too weak to cushion households from health shocks (Leive \& Xu, 2008). Therefore, having health insurance is pivotal as it significantly aids medical treatment by reducing Out-of-Pocket (OOP) expenses whenever any member of a particular family or household becomes ill (World Bank, 2014). Health expenditures are defined based on the predominant purposes they serve in terms of improving health. They encompass health machinery and equipment costs, treatment costs, medical care costs, and health recurrent expenditures. Health care is primarily financed by OOP expenditure in less developed countries as well as in developing economies. Households without any form of medical cover are very likely to spend more money when their loved ones fall ill. In such unforeseen and unplanned circumstances, these medical expenditures are more likely to exhaust a household's stream of income. Furthermore, financially constrained households may be compelled to borrow or even sell-off their assets, i.e., land, just to meet these necessary health expenses. This lowers a household's living standard (Krishna, 2006).

According to the World Economic Forum report (2019), every year 6 million people die in low-income countries as a result of low-quality health care. This scenario is not different for Kenya. Despite efforts by the government in increasing the budgetary allocation to the health sector, the health status of many Kenyans has not improved significantly. More concretely, Kenya's Universal Health Coverage (UHC) service index stands at 55 (World Bank, 2018). This is a decline from the 57 recorded in 2015 (WHO, 2017). This figure is way less than that of many other 86 recorded countries that are performing comparatively better as far as UHC is concerned.

More importantly, the Government of Kenya through the 'Big Four Agenda' priorities aims at achieving UHC by providing financial protection to its citizens against the OOP expenditure. The agenda stipulates a reduction in the OOP household expenditure from 26\% recorded in 2017 to $12 \%$ by the year 2022 (The Big Four, 2017). Achieving the UHC remains a tall order milestone for Kenya with only 16,538,982 persons (representing 36\%) of the total population reported to have been well-insured by the year 2017. This largely falls short of the targeted cover of about 51,572,636 persons (representing 100\%) of the total population by the year 2022 (The Big Four, 2017). 
The problem is also compounded by health shocks that result in a sharp upsurge in the health care expenditure pattern at both the household and government levels. This compels Kenya to rely on donor funding in the wake of such health pandemics and epidemics, i.e., HIV/AIDs and cancer. The massive strides made by the government of Kenya in ensuring UHC have been constantly thwarted due to a lack of adequate knowledge on the core predisposing factors that determine health care expenditure. This study, therefore, seeks to address this problem by identifying the drivers of public health care expenditure that are uniquely critical to the Kenyan economy's health care context. More importantly, this study will contribute to the existing literature by examining the role of structural breaks in determining public health expenditure. Previously, this is something that has been largely omitted in the Kenyan context.

Health shocks are defined as unpredictable diseases that are highly cost-demanding and that cause a sudden deterioration to an individual's health status (Atake, 2018). Leive and $\mathrm{Xu}$ (2008) identified Illness as the most important shock associated with poverty in Less Income Countries (LICs). Approximately 100 million people plunge into poverty annually due to health care costs (World Bank, 2014). According to Leive and Xu (2008), health shocks exert a double financial burden on households through not only increased medical treatment costs but also the loss of income that is associated with the inability to work. With the bulk of healthcare expenditure in LICs being financed through OOP payments, the majorities of households suffer the huge financial burden of accessing quality medical care and may alternatively have to forego it all together (Xu et al., 2003). Wagstaff (2008) observes that calamitous health care expenditures combined with foregone earnings may plunge households into the health poverty trap.

There is, therefore, a dire need for heavy investment in the health care system in Kenya. The government of Kenya has been shouldered with the massive task of ensuring Universal Health Care for its citizens, which is one that is not only accessible but also affordable. Consequently, various proponents of public health investment argue that it reduces the size of OOP expenses. This relieves the population from poverty brought forth by catastrophic health expenditure. The World Health Organization notes that universal health care can be realized through health insurance which has been identified as a core driver in gearing financial protection (WHO, 2010). Studies on less developed and developing countries have revealed that OOP is just too high and unaffordable, thus plunging many families into poverty (Galarraga et al., 2009).

The life expectancy in Kenya averages 61 years with the key obstacle to longer life expectancy being death accruing from HIV/AIDS, high under 5 child mortality rates, communicable \& non-communicable diseases, and the 
deadly emerging cancerous infections. Currently, the total annual death in Kenya is approximately 420,000 people. Government statistics reveal that out of these deaths, approximately 270,000 deaths are caused by communicable diseases with non-communicable diseases accounting for about 110,000 deaths. Moreover, deaths from injuries can be approximated at 40,000 persons (Republic of Kenya, 2012). Nonetheless, Statistics from The Dutch Republic (2016) show that Kenya performs better in terms of life expectancy in comparison to other African countries. For instance, Uganda's, Zambia's, South Africa's, and Nigeria's life expectancies are 59, 58, 60, and 55 years, respectively, which are lower than that of Kenya.

The government of Kenya has made substantial efforts in improving health services and outcomes over the past decade. These efforts have not only resulted in reduced child mortality rates but also decreased infections from communicable and non-communicable diseases. Statistics from the Republic of Kenya (2017) indicate that the number of under 5 death rates declined to 52 in 1000 live birth in 2014 from 115 in 1000 live birth in 2003. This represented a $54 \%$ decline over the same period. Kenya's infant mortality rate declined to 39 in 1000 live birth in 2014 from the 77 in 1000 live births recorded in 2003. However, on the negative side, the neonatal mortality rate remains high and accounts for approximately $35 \%$ of the infant mortality rate. Furthermore, the maternal death rate is still high at 362 deaths for every 100,000 live births.

This encouraging trend directly stems from the health care funding initiative from the government. The funding emanates from three major sources, namely: Out-of-Pocket (OOP) expenditure, donors, and government expenditure. Due to very high OOP expenses, accessibility to health care services in Kenya is still yet to be fully realized. According to Munge and Briggs (2013), many Kenyans fail to access health care services as a result of high medical fees. The study further revealed that the number of mothers and patients seeking health services rose due to health insurance that does away with user fees (fully or partially) in health facilities in Kenya. Donor funding remains a vital contributor as far as the financing of health care in Kenya is concerned. It does not only augment the government's budgetary allocation but also sponsors specific programs such as the fight against HIV/AIDS. According to the Ministry of Health (2016), donor funding accounted for about $32 \%$ of the total health spending. Donor funding supplements health care expenditure immensely, hence decreasing the OOP health expenditures.

The national government also plays a massive role in health care financing in Kenya. It allocated 59.2 billion Kenya Shillings to the health sector in the 2017/18 fiscal year with the figure, however, declining to 47.4 billion in the 2018/19 fiscal year. Since health is a devolved function in Kenya, the county governments have equally been shouldered with the responsibility of financing the sector through counties' budget allocation (Republic of 
Kenya, 2017; 2018). Therefore, this reveals the commitment towards achieving Universal Health Care as shown in Table 1.

Table 1. National and County governments' budgetary allocation to the Kenyan Health

\begin{tabular}{|l|l|l|l|l|}
\hline Financial Year & $\begin{array}{l}\text { National } \\
\text { government } \\
\text { (KES. Billion) }\end{array}$ & $\begin{array}{l}\text { County } \\
\text { governments } \\
\text { (KES. Billion) }\end{array}$ & $\begin{array}{l}\text { Total (KES. } \\
\text { Billion) }\end{array}$ & $\begin{array}{l}\text { Percentage } \\
\text { year-on-year } \\
\text { change in Total }\end{array}$ \\
\hline $\mathbf{2 0 1 8 / 1 9}$ & 47.4 & 68.2 & 115.6 & - \\
\hline $\mathbf{2 0 1 7 / 1 8}$ & 59.2 & 86.7 & 145.9 & $26.2 \%$ \\
\hline $\mathbf{2 0 1 6 / 1 7}$ & 60.3 & 95.8 & 156.1 & $7 \%$ \\
\hline $\mathbf{2 0 1 5 / 1 6}$ & 61.6 & 107.5 & 169.1 & $8.4 \%$ \\
\hline $\mathbf{2 0 1 4 / 1 5}$ & 47.4 & 68.2 & 115.6 & $20 \%$ \\
\hline
\end{tabular}

Source: (Republic of Kenya: National Treasury Programme-based budget, 2014/15-2018/19)

Despite the governments' efforts in achieving the UHC, Kenya's health care budget is still yet to meet the provisions of the Abuja Declaration. This is a 2001 pledge by African countries to allocate at least $15 \%$ of their annual budgets towards health care (WHO, 2001). With proper utilization of the $15 \%$ set target, it is projected that countries will be able to significantly improve their infrastructure, security, education, and the governance structures of their economies as a whole.

The rest of the paper is structured as follows: Chapter two will review the existing literature. Chapter three will present the methodology. Chapter four will discuss the results while the final chapter will provide conclusions and policy implications.

\section{Literature Review}

Health care is a good investment due to its intermediary role in generating future productive days. The Grossman model of health care services borrows a great deal from the human capital hypothesis (Becker, 1964; Mincer, 1974). Grossman (1972) analyzed the role of human capital using a stock approach for health. Investment in health care services generates good health which helps in not only improving individual productivity but also enters the utility function through the production of commodities. Grossman (1972) envisages health as a durable capital stock that yields an output of healthy time. In this respect, consumers inherit an initial amount of this stock. This amount depreciates as the age of an individual increase but can be boosted by investment. The theory accounts for the gap between input (which is medical care) and output (health) which then ultimately enters into the production function. This link between inputs and outputs is then analyzed by the use of a health production function. Health care expenditure is treated as a function of human capital investment. 
According to Baumol (1993), there is a tendency of relative prices of some services to rise in comparison to other commodities in the economy, thus, demanding sectoral wage equalization. More precisely, health care prices will increase relative to the prices of other commodities since wages in the less productive sectors need to keep up with wages in the more productive sectors. This theory explains the relationship between health care cost, laborers' wages, and the share of health care expenditure in GDP. A study on the rising health spending and the integration of new medical technology by Pomp and Vujic (2008) observed that in most Organization for Economic Co-operation \& Development (OECD) countries, the rise in health expenditure as a share of GDP is most likely caused by the Baumol effect. Additionally, with an inelastic health care demand, then health spending will most likely increase over time.

Rahman (2008) investigated the determinants of public health expenditure in India using a panel data analysis approach. The study categorized expenditure into regional health expenditure and structural demand variables. The findings revealed that literacy rate and per capita income (real state) significantly determined regional health care. Conversely, the proportion of the state population above the age of 60 and other structural factors were found to be statistically insignificant.

Byaro et al. (2018) investigated the major drivers of per capita public health expenditure growth in Tanzania using nationally representative annual data between 1995 and 2014. The study estimated the Bayesian model premised on the Markov Chain Monte Carlo (MCMC) simulation technique. The findings revealed that per capita real GDP and age of the population (65 years and above) positively influenced health expenditure. On the other hand, advancement in medical technologies (proxied by life expectancy) negatively determined health expenditure.

In a study to examine the drivers of public health care expenditure, Boachie et al. (2014) used a 1970-2008 Ghanaian dataset. The study assessed the relationship between public health care expenditure and the socioeconomic \& environmental indicators using the Elliot Rothenberg \& Stock (ERS) unit root and the Engle-Granger cointegration tests. The study investigated the long-run impacts of inflation, crude birth rate, real GDP, urbanization, $\mathrm{CO}_{2}$ emissions, and life expectancy on public health care expenditure in Ghana using the Fully Modified Ordinary Least Squares (FMOLS) method. The results revealed a positive and significant impact of life expectancy, real GDP, and crude birth rates on public health expenditure. Life expectancy was measured by the degree of the healthiness of the population, while crude birth rate denoted the yearly number of births for every 1000 population. The Inflation rate, $\mathrm{CO}_{2}$ emissions, and urbanization were found to be statistically insignificant. The study thus concluded that 
healthcare was a necessity in Ghana. In an extended view, Murthy and Okunade (2009) find health to be a necessity and not a luxury good in OECD countries.

Buigut et al. (2015) studied the drivers of calamitous health expenditures in Kenyan urban slum communities. The study employed data from informal urban household settlements. From the multivariate logistic regression analysis results, an individual's membership to a social security scheme, and the number of working adults in a household, significantly reduced the risk of catastrophic expenditure. Conversely, the risk of catastrophic expenditure was significantly increased for those individuals who sought private or public hospital care. The study thus suggested risk pooling (insurance) as a mechanism towards protecting medical-seeking slum dwellers.

Gbesemete and Gerdtham (1992) find a close to unity income elasticity of health expenditure in a pooled analysis study involving selected 30 African countries. This implied that a household's income level significantly determined the health care expenditure. This was especially true for the case of OOP Expenditures where individuals have to finance their health expenditures directly from their pockets.

In a study conducted in the Netherlands by Grossman (1972), the price of a given health care cover or product was found to significantly determine health care expenditure in the public sector. In a related study, Grossman (2000) finds education to be a significant driver of health care expenditure. The level of education of an individual determines the rate of exposure to a certain health outcome which ultimately determines its expenditure. Human capital thus directly determines health care expenditure.

Newhouse (2002) examined the impact of technological progress (proxied by surgical procedures and the quality of medical equipment, infant mortality rates, and life expectancy) on health care expenditure. The study findings revealed that technological progress significantly determined health care expenditure. Technological innovations were cited as the main contributing factors to increasing health care costs. This was due to the costly nature of most of the advanced health care machinery and equipment as well as the positive relationship between technological advancement and health care expenditure.

The study by Tang (2010) investigated the drivers of health expenditure for Malaysia using data from 1967-2007. The price of health care, the percentage of the population aged above 65 years, and income were found to have a positive and long-run significant impact on health care expenditure. The study, thus, recommended the enactment of cost-effective health expenditure policies in a bid to ensure UHC. The study of Ang (2010) found a higher than one income elasticity for health care in Australia, which implied 
that health care was a good luxury. Similarly, the study revealed that the more accessible health care services were, the higher the health expenditure.

Bonfrer and Gustaffson (2016) surveyed 1226 Kenyan agricultural households that were selected through random sampling. The study aimed at identifying the role of health shocks and the related coping behavioral strategies. Injury and illness shocks were found to dominate over all other prevalent shocks with almost $2 \%$ of households incurring calamitous health expenditure in the previous year. The study concluded that health shocks indeed posed a significant risk to households, hence, the need to implement pre-payment or saving mechanism schemes.

Most of these reviewed studies explore health care determinants in the developing economies context with very few targeting developing countries. Health shocks emanating from $\mathrm{CO}_{2}$ emissions and unforeseen diseases, particularly HIV/AIDs, will be investigated in this study. More critical are the structural breaks that may result in a sharp upward or downward surge in public health expenditure. These are never factored in when estimating health care expenditure models in the Kenyan context. As a result, previous health expenditure studies in Kenya have, thus, yielded less accurate estimates with reduced forecast power. This study will, thus, contribute to the existing literature by incorporating the structural break dummy variables into the model.

\section{METHODOLOGY}

\subsection{Empirical Model Specification}

This research intends to examine the drivers of Public Health Expenditure (PHE) in Kenya. From the reviewed literature, PHE will be expressed as a function of the following economic variables: GDP per capita (GDP), HIV/AIDs infections (HIV), Age above 65 years (AGE), Population growth rate (POP), and $\mathrm{CO}_{2}$ emissions in metric tons per capita $\left(\mathrm{CO}_{2}\right)$. Hence the empirical model can be specified as follows:

$$
\begin{array}{r}
\ln (P H E)_{t}=\beta_{0}+\beta_{1} \ln (G D P)_{t}+\beta_{2} \ln (H I V)_{t}+\beta_{3}(A G E)_{t}+\beta_{4}(P O P)_{t}+\beta_{5}\left(C O_{2}\right)_{t}+ \\
\mu_{t} \ldots \ldots \ldots(1)
\end{array}
$$

Where the $\boldsymbol{\beta}_{\boldsymbol{s}}$ represent the population parameters, $\boldsymbol{\mu}$ denotes the stochastic error term, and $\mathbf{t}$ is the time trend. $\boldsymbol{l n}$ is the natural logarithm. Logarithmic transformation of the model is vital in controlling the outliers that may potentially arise among the variables. It helps in normalizing the data. This paper makes a major contribution by examining the role of structural breaks in determining public health expenditure in Kenya. As such, estimated break dates are to be determined using Zivot and Andrews (1992) unit root 
test. Thereafter, structural break dummies are generated and incorporated into the public health expenditure model as shown in equation 2 .

$$
\begin{aligned}
& \ln (P H E)_{t}=\beta_{0}+\beta_{1} \ln (G D P)_{t}+\beta_{2} \ln (H I V)_{t}+\beta_{3}(A G E)_{t}+\beta_{4}(P O P)_{t}+\beta_{5}\left(C O_{2}\right)_{t}+ \\
& \beta_{6}(S B D)_{t}+\beta_{7}\left(S B D * X_{i}\right)_{t}+\mu_{t}
\end{aligned}
$$

Where $\boldsymbol{S B D}$ is the structural break dummy and $\boldsymbol{X}_{\boldsymbol{i}}$ are the explanatory variables already specified in equation 1. $\left(\boldsymbol{S} \boldsymbol{B} \boldsymbol{D} * \boldsymbol{X}_{\boldsymbol{i}}\right)$, thus, denotes the interactive structural dummy variables. In modeling the ARDL Bounds testing procedure as developed by Pesaran and Smith (1999) and Pesaran et al. (2001), the null hypothesis postulates that there is No Cointegration. If the F statistic is less than the I (1) upper bound critical values, the null hypothesis of No Cointegration is not rejected. In the absence of Cointegration, the short-run (ARDL) model is specified and estimated as shown by equation 3 :

$$
\begin{aligned}
& \Delta \ln (P H E)_{t}=\beta_{0}+\sum_{i=1}^{q_{1}} \gamma_{i} \Delta \ln (P H E)_{t-i}+\sum_{i=0}^{q_{1}} \partial_{i} \Delta \ln (G D P)_{t-i}+ \\
& \sum_{i=0}^{q_{2}} \delta_{i} \Delta \ln (H I V)_{t-i}+\sum_{i=0}^{q_{3}} \vartheta_{i} \Delta(A G E)_{t-i}+ \\
& \sum_{i=0}^{q_{4}} \theta_{i} \Delta(P O P)_{t-i}+\sum_{i=0}^{q_{5}} \varphi_{i} \Delta\left(C O_{2}\right)_{t-i}+\sum_{i=0}^{q_{6}} \rho_{i}(S B D)_{t-i}+\sum_{i=0}^{q_{7}} \sigma_{i}\left(S B D * X_{i}\right)_{t-i}+
\end{aligned}
$$$$
\mu_{t}
$$

Where $\Delta$ denotes the Difference operator.

If the F statistic is greater than the I (1) upper bound critical values, the null hypothesis of No Cointegration is rejected implying that Cointegration does exist. The long-run relationship is, thus, modeled and, consequently, the Error Correction Model (ECM) is estimated as shown in equation 4.

$$
\begin{aligned}
& \Delta \ln (P H E)_{t}=\beta_{0}+\sum_{i=1}^{q_{1}} \gamma_{i} \Delta \ln (P H E)_{t-i}+\sum_{i=0}^{q_{1}} \partial_{i} \Delta \ln (G D P)_{t-i}+ \\
& \sum_{i=0}^{q_{2}} \delta_{i} \Delta \ln (H I V)_{t-i}+\sum_{i=0}^{q_{3}} \vartheta_{i} \Delta(A G E)_{t-i}+\sum_{i=0}^{q_{4}} \theta_{i} \Delta(P O P)_{t-i}+\sum_{i=0}^{q_{5}} \varphi_{i} \Delta\left(C O_{2}\right)_{t-i}+ \\
& \sum_{i=0}^{q_{6}} \rho_{i}(S B D)_{t-i}+\sum_{i=0}^{q_{7}} \sigma_{i}\left(S B D * X_{i}\right)_{t-i}+
\end{aligned}
$$



Where $\boldsymbol{\gamma}_{\boldsymbol{i}}, \boldsymbol{\partial}_{\boldsymbol{i}}, \boldsymbol{\delta}_{\boldsymbol{i}}, \boldsymbol{\vartheta}_{\boldsymbol{i}}, \boldsymbol{\theta}_{\boldsymbol{i}}, \boldsymbol{\varphi}_{\boldsymbol{i}}, \boldsymbol{\rho}_{\boldsymbol{i}}$, and $\boldsymbol{\sigma}_{\boldsymbol{i}}$ are the short - run dynamic coefficients of the models' Adjustment Long - run equilibrium. $K$ is the speed adjustment parameter with a negative sign and denotes model convergence in the long - run. $\boldsymbol{E C T}$ is the Error Correction Term while q denotes the optimal lag length. 


\subsection{Descriptive Statistics}

This is presented in Table 2 below.

Table 2. Descriptive statistics

\begin{tabular}{l} 
Variable \\
\hline Public health expenditure (PHE)
\end{tabular}

\section{Description and Measurement}

The total annual public expenditure on the health sector in Kenya shillings (KES). PHE is defined in its natural logarithm.

GDP per capita (GDP)

This refers to Kenya's total economic output per person and is obtained by dividing the GDP by its population. It is measured in KES but will be expressed in a natural logarithm.

HIV/AIDs infections (HIV) The annual number of people infected and living with HIV/AIDs. It is expressed in a natural logarithm.

Age above 65 years (AGE)

Population growth rate (POP)

$\mathrm{CO}_{2}$ emissions $\left(\mathrm{CO}_{2}\right)$ The yearly proportion of the number of adults with a population age of 65 years and above.

The annual rate of growth of the population.

The annual amount of $\mathrm{CO}_{2}$ emissions in metric tons per capita.

Source: Author's description

\subsection{Data Type and Source}

This study employed time series data for the period 1985-2018. Data on $\mathrm{CO}_{2}$ emissions, population growth rate, GDP per capita, and age above 65 years was obtained from the World Bank database. Data on public health expenditure was obtained from the Ministry of Health, National Treasury \& Planning, and Kenya National Bureau of Statistics statistical reports and abstracts. Finally, data on HIV/AIDs was sourced from the National AIDs Control Council (NACC) database.

\subsection{Summary Statistics}

This is shown in Table 3 below.

Table 3. Summary statistics of variables $(N=34)$

\begin{tabular}{|l|l|l|l|l|}
\hline Variable & Mean & Std. dev. & Min. & Max. \\
\hline Public health expenditure & $3.23 \mathrm{e}+10$ & $4.75 \mathrm{e}+10$ & $8.41 \mathrm{e}+07$ & $1.69 \mathrm{e}+11$ \\
\hline GDP per capita & 672232.6 & 426711.6 & 220070 & 1707987 \\
\hline HIV/AIDs infections & 1190889 & 373590.1 & 420000 & 1929000 \\
\hline Age above 65 years & 2.2591 & 0.2118 & 1.932 & 2.647 \\
\hline Population growth rate & 2.9041 & 0.3829 & 2.306 & 3.745 \\
\hline $\mathrm{CO}_{2}$ emissions & 0.2751 & 0.0542 & 0.19 & 0.38 \\
\hline
\end{tabular}

Source: Compiled from Stata

Table 3 shows that the annual average amount of money spent by the government in the Kenyan health sector was 32.3 Billion Kenya shillings (KES). The variable also had the highest standard deviation of 47,500,000,000 around the mean value. The lowest amount of money allocated to the public health sector was KES. 84, 100, 000 with the highest being KES. 169 Billion. Public health expenditure was lower in the earlier years due to low levels of economic growth and development but has been steadily increasing annually. 
With devolution taking effect in 2013, the budgetary allocation to the health sector rose tremendously. GDP per capita averaged approximately KES. 672, 232 with a dispersion rate of 426, 711, and varied in the intervals of 220, 070 and 1,707, 987. On average, 1, 190, 889 people are infected and living with HIV/AIDs in Kenya. The proportion of the number of adults with a population age of 65 years and above averaged about $2.26 \%$, while Kenya's population growth rate averaged $2.90 \%$ per annum. The average annual amount of $\mathrm{CO}_{2}$ emissions in metric tons per capita was recorded at $0.28 \%$ with a standard deviation of 0.05 and is varied within the intervals of 0.19 and 0.38 .

\section{Results}

4.1 Pre-Estimation Tests

\subsubsection{Unit Root Test}

Testing for the order of integration for each variable in the model is vital as it helps in avoiding potential spurious and or inconsistent regression, i.e., having more than one trend in the series. The Augmented Dickey-Fuller test after Dickey and Fuller (1979) and the Phillips and Perron (1988) unit root tests yielded the following results (See Table 4). 
Table 4. Stationarity test results

\begin{tabular}{|c|c|c|c|c|c|c|c|}
\hline \multirow[t]{2}{*}{ Variable } & \multicolumn{4}{|l|}{ ADF test } & \multicolumn{3}{|c|}{ Phillips-Perron (PP) test } \\
\hline & $\begin{array}{l}\text { Testing } \\
\text { level }\end{array}$ & $\begin{array}{l}\text { Test } \\
\text { Statistic }\end{array}$ & $\begin{array}{l}\text { Critical } \\
\text { Value } \\
(5 \%)\end{array}$ & $\begin{array}{c}\text { Order of } \\
\text { Integration }\end{array}$ & $\begin{array}{l}\text { Test } \\
\text { Statistic } \\
Z(t)\end{array}$ & $\begin{array}{l}\text { Critical } \\
\text { Value } \\
(5 \%)\end{array}$ & $\begin{array}{c}\text { Order of } \\
\text { Integration }\end{array}$ \\
\hline $\begin{array}{l}\text { InPublic Health } \\
\text { Expenditure }\end{array}$ & $\begin{array}{l}\text { Level } \\
1^{\text {st }} \mathrm{D} \\
\end{array}$ & $\begin{array}{l}-0.747 \\
-5.852 \\
\end{array}$ & $\begin{array}{l}-2.978 \\
-2.980 \\
\end{array}$ & $\mathrm{I}(1)$ & $\begin{array}{l}-0.708 \\
-5.864 \\
\end{array}$ & $\begin{array}{l}-2.978 \\
-2.980 \\
\end{array}$ & $\mathrm{I}(1)$ \\
\hline $\begin{array}{c}\text { lnGDP per } \\
\text { capita }\end{array}$ & $\begin{array}{l}\text { Level } \\
1^{\text {st }} \mathrm{D} \\
\end{array}$ & $\begin{array}{l}0.538 \\
-4.156 \\
\end{array}$ & $\begin{array}{l}-2.978 \\
-2.980 \\
\end{array}$ & $\mathrm{I}(1)$ & $\begin{array}{l}0.308 \\
-4.142 \\
\end{array}$ & $\begin{array}{r}-2.978 \\
-2.980 \\
\end{array}$ & $\mathrm{I}(1)$ \\
\hline $\begin{array}{l}\text { lnHIV/AIDs } \\
\text { infections }\end{array}$ & $\begin{array}{l}\text { Level } \\
1^{\text {st }} \mathrm{D}\end{array}$ & $\begin{array}{l}-2.863 \\
-4.372\end{array}$ & $\begin{array}{l}-2.978 \\
-2.980\end{array}$ & I (1) & $\begin{array}{l}-2.684 \\
-4.407\end{array}$ & $\begin{array}{l}-2.978 \\
-2.980\end{array}$ & $\mathrm{I}(1)$ \\
\hline $\begin{array}{c}\text { Age above } 65 \\
\text { years }\end{array}$ & $\begin{array}{l}\text { Level } \\
1^{\text {st }} \mathrm{D} \\
2^{\text {nd }} D\end{array}$ & $\begin{array}{l}-2.246 \\
0.764 \\
-5.052\end{array}$ & $\begin{array}{l}-2.978 \\
-2.980 \\
-2.983\end{array}$ & I (2) & $\begin{array}{l}-1.835 \\
0.788 \\
-5.070\end{array}$ & $\begin{array}{l}-2.978 \\
-2.980 \\
-2.983\end{array}$ & I (2) \\
\hline $\begin{array}{l}\text { Population } \\
\text { growth rate }\end{array}$ & Level & -3.219 & -2.978 & $\mathrm{I}(0)$ & $\begin{array}{l}-2.027 \\
-1.299 \\
-1.877 \\
-3.503\end{array}$ & $\begin{array}{l}-2.978 \\
-2.980 \\
-2.983 \\
-2.986\end{array}$ & I (3) \\
\hline $\mathrm{CO}_{2}$ emissions & $\begin{array}{l}\text { Level } \\
1^{\text {st }} \mathrm{D}\end{array}$ & $\begin{array}{l}-1.646 \\
-6.883\end{array}$ & $\begin{array}{l}-2.978 \\
-2.980\end{array}$ & I (1) & $\begin{array}{l}-1.647 \\
-6.866\end{array}$ & $\begin{array}{l}-2.978 \\
-2.980\end{array}$ & I (1) \\
\hline
\end{tabular}

Source: Stata computation

Notes: D denotes Difference.

\subsubsection{Unit Root Test in the Presence of Structural Breaks}

Testing for structural breaks in time-series economics has become extremely relevant in recent times (Glynn et al., 2007). Structural break(s) normally arise when there is a sudden unexpected shift or abrupt change in the time-series variables at a certain point in time. This abrupt change causes a change in the mean or a shift in other parameters in the series, hence, leading to unrealistic estimated parameters. If not controlled, structural breaks may result in incorrect forecasting. Some of the factors that can lead to structural breaks include economic boom or recession, natural calamities, war, political instability, disease pandemic, financial crises, etc. Also, Zivot and Andrews (1992) observed that the traditional unit root tests like ADF become ineffective in testing for a unit root when structural breaks are present.

Zivot and Andrews (1992) and Pesaran (2015) further revealed that both PP and ADF tests are asymptotically equivalent, have lower power, and do fail to reject the invalid null hypothesis in the case where the coefficient in AR (1) process is close to one. Testing for structural breaks, thus, yields a more accurate forecast in time-series analysis when compared to other studies that ignore the structural breaks (Ndirangu et al., 2014). If structural breaks are detected, then structural break dummy variables will be generated and included in the time-series regression model. This study, thus, employed the Zivot and Andrews (1992) unit root test to capture the structural breaks (see Table 5). 
Table 5. Zivot-Andrews Unit Root Test results

\begin{tabular}{|c|c|c|c|c|c|}
\hline \multicolumn{6}{|c|}{ Break in Intercept and Trend } \\
\hline Variables & $\begin{array}{l}\text { Structural } \\
\text { break date/year }\end{array}$ & Testing level & t-statistics & $\begin{array}{l}\text { Critical } \\
\text { value }(5 \%)\end{array}$ & $\begin{array}{l}\text { Integration } \\
\text { Order }\end{array}$ \\
\hline $\begin{array}{l}\text { InPublic Health } \\
\text { Expenditure }\end{array}$ & 1998 & Level & -12.460 & -4.80 & $\mathrm{I}(0)$ \\
\hline $\begin{array}{c}\text { lnGDP per } \\
\text { capita }\end{array}$ & $\begin{array}{l}1991 \\
1994\end{array}$ & $\begin{array}{l}\text { Level } \\
1^{\text {st }} \mathrm{D}\end{array}$ & $\begin{array}{l}-3.378 \\
-5.919\end{array}$ & $\begin{array}{l}-4.80 \\
-5.08\end{array}$ & $\mathrm{I}(1)$ \\
\hline lnHIV infections & $\begin{array}{l}1991 \\
2000\end{array}$ & $\begin{array}{l}\text { Level } \\
1^{\text {st }} \mathrm{D}\end{array}$ & $\begin{array}{l}-4.360 \\
-6.860\end{array}$ & $\begin{array}{l}-4.80 \\
-5.08\end{array}$ & $\mathrm{I}(1)$ \\
\hline $\begin{array}{c}\text { Age above } 65 \\
\text { years }\end{array}$ & $\begin{array}{l}2013 \\
2006\end{array}$ & $\begin{array}{l}\text { Level } \\
1^{\text {st }} \mathrm{D}\end{array}$ & $\begin{array}{l}-0.944 \\
-6.840\end{array}$ & $\begin{array}{l}-4.80 \\
-5.08\end{array}$ & $\mathrm{I}(1)$ \\
\hline $\begin{array}{l}\text { Population } \\
\text { growth rate }\end{array}$ & $\begin{array}{l}2003 \\
2006\end{array}$ & $\begin{array}{l}\text { Level } \\
1^{\text {st }} \mathrm{D}\end{array}$ & $\begin{array}{l}-4.206 \\
-5.730\end{array}$ & $\begin{array}{l}-4.80 \\
-5.08\end{array}$ & $\mathrm{I}(1)$ \\
\hline $\mathrm{CO}_{2}$ emissions & 2002 & Level & -5.646 & -4.80 & $\mathrm{I}(0)$ \\
\hline
\end{tabular}

Since the Zivot-Andrews's unit root test results (in Table 5) revealed that the variables were integrated with a mixture of order 0 and 1, the ARDL model was adopted (Pesaran \& Shin, 1999; Pesaran et al., 2001). This model is advantageous in the sense that it does not require all variables to be integrated of the same order. ARDL is also efficient in cases where small and finite sample data sizes are involved. Furthermore, Harris and Sollis (2003) observe that the model yields unbiased long-run estimates.

\subsubsection{ARDL Bounds Test}

Since the variables were found to be integrated by a mixture of order I (0) \& I (1), the ARDL bounds testing procedure became applicable (Pesaran \& Shin, 1999; Pesaran et al., 2001). It is possible to test for Cointegration within the ARDL framework. Therefore, the ARDL bounds test results are shown in Table 6.

Table 6. ARDL Bounds Test Results

\begin{tabular}{|l|l|l|l|l|}
\hline & $\mathbf{1 0 \%}$ & $\mathbf{5 \%}$ & $\mathbf{2 . 5 \%}$ & $\mathbf{1 \%}$ \\
\hline I (0) values & 1.95 & 2.22 & 2.48 & 2.79 \\
\hline I (1) values & 3.06 & 3.39 & 3.70 & 4.10 \\
\hline \multicolumn{5}{|r|}{ F statistic $=\mathbf{5 . 0 5 4}$} \\
\hline
\end{tabular}

Source: Stata computation

Table 6 revealed that the $F$ statistic was greater than the I (1) upper bound critical values; hence, the null hypothesis of No Cointegration was rejected. This implied that Cointegration did exist. An Error Correction Model (ECM) was thus fitted within the ARDL framework to capture both the shortrun and long-run relationships. 


\subsection{Empirical Findings}

Several diagnostic tests were performed to ascertain the validity and accuracy of the public health expenditure model results. The Breusch and Pagan (1979) heteroskedasticity test revealed that the model was homoscedastic $(0.6756>0.05)$. The optimal lags adopted by Akaike Information Criterion (AIC) automatic lag selection were 1, 2, 2, 0, 1, and 1. The Breusch and Godfrey (1978) LM autocorrelation test was employed with the results revealing that the error terms were not serially correlated $(0.0661>0.05)$. In checking for normality, the Jarque-Bera (1987) test was employed. With the probability value of chi-squared reported to be 0.633 , which is greater than the 0.05 significance level, the null hypothesis of Normality was not rejected implying that the residuals followed a normal distribution. The models (with and without the structural break dummies) were then estimated with the results presented in Table 7.

Table 7. ARDL Model results

\begin{tabular}{|c|c|c|}
\hline \multirow[t]{2}{*}{ Dependent variable: lnPublic Health Expenditure } & \multicolumn{2}{|c|}{ Coefficients } \\
\hline & $\begin{array}{c}\text { Model 1: Without } \\
\text { structural break } \\
\text { dummies. }\end{array}$ & $\begin{array}{c}\text { Model 2: With } \\
\text { structural break } \\
\text { dummies. }\end{array}$ \\
\hline Error Correction Term (ECT) & $\begin{array}{l}-0.712 * * * \\
(0.174)\end{array}$ & $\begin{array}{l}-0.757 * * * \\
(0.171)\end{array}$ \\
\hline \multicolumn{3}{|c|}{ Long-Run Relationship } \\
\hline lnGDP per capita & $\begin{array}{l}5.563 * * * \\
(1.490)\end{array}$ & $\begin{array}{l}5.553 * * * \\
(1.490)\end{array}$ \\
\hline lnHIV AIDs infections & $\begin{array}{l}5.303^{*} \\
(2.918)\end{array}$ & $\begin{array}{l}5.143^{*} \\
(2.879)\end{array}$ \\
\hline Age above 65 years & $\begin{array}{l}3.984 * \\
(2.271)\end{array}$ & $\begin{array}{l}3.542 \\
(2.361)\end{array}$ \\
\hline Population growth rate & $\begin{array}{l}1.870 \\
(2.872)\end{array}$ & $\begin{array}{l}2.499 \\
(2.689)\end{array}$ \\
\hline $\mathrm{CO}_{2}$ emissions & $\begin{array}{l}-16.28 \\
(10.81)\end{array}$ & $\begin{array}{l}-12.68 \\
(12.50)\end{array}$ \\
\hline$S B D$ & - & $\begin{array}{l}364.6^{*} \\
(189.6)\end{array}$ \\
\hline$S B D^{*} \ln G D P$ per capita & - & $\begin{array}{l}-25.80^{*} \\
(13.72)\end{array}$ \\
\hline SBD* Population growth rate & - & $\begin{array}{l}-11.16^{* *} \\
(5.024)\end{array}$ \\
\hline Short-Run Relati & hip & \\
\hline D. lnGDP per capita & $\begin{array}{l}-3.432 * * * \\
(1.113)\end{array}$ & $\begin{array}{l}-3.498 * * * \\
(1.038)\end{array}$ \\
\hline LD. lnGDP per capita & $\begin{array}{l}-3.434 * * * \\
(1.176)\end{array}$ & $\begin{array}{l}-3.919 * * * \\
(1.101)\end{array}$ \\
\hline D. lnHIV AIDs infections & $\begin{array}{l}-2.855^{*} \\
(1.502)\end{array}$ & $\begin{array}{l}-2.480 \\
(1.615)\end{array}$ \\
\hline LD. lnHIV AIDs infections & $\begin{array}{l}-3.105^{* * *} \\
(1.432)\end{array}$ & $\begin{array}{l}-4.103 * * \\
(1.710)\end{array}$ \\
\hline
\end{tabular}




\begin{tabular}{lll} 
D. Population growth rate & $22.50 * *$ & $24.02 * * *$ \\
& $(8.360)$ & $(7.945)$ \\
D. $\mathrm{CO}_{2}$ emissions & $12.60^{* *}$ & $16.77 * *$ \\
& $(5.100)$ & $(5.781)$ \\
Constant & $-94.87 * *$ & $-100.5 * *$ \\
& $(38.44)$ & $(39.34)$ \\
R squared & 0.6684 & 0.7634 \\
Adj. R squared & 0.4589 & 0.5416 \\
Observations (N) & 32 & 32 \\
Jarque-Bera Normality test & Prob $>X^{2}=0.633^{* *}$ & Prob $>X^{2}=0.1466^{* *}$ \\
Breusch-Pagan heteroskedasticity test & Prob $>X^{2}=0.6756^{* *}$ & Prob $>X^{2}=0.8252^{* *}$ \\
Breusch-Godfrey LM Autocorrelation test & Prob $>X^{2}=0.0661^{* *}$ & Prob $>X^{2}=0.0549 * *$ \\
\hline
\end{tabular}

$$
\begin{aligned}
& \text { Standard errors in parentheses } \\
& * * * \mathrm{p}<0.01, * * \mathrm{p}<0.05, * \mathrm{p}<0.1
\end{aligned}
$$

Notes: L denotes lag while $\mathbf{S B D}$ is the generated Structural Break Dummy variable. The variable was also interacted with $\ln G D P$ per capita and Population growth rate to assess the effect of these interactive term break variables on public health expenditure. We did not interact the break dummy variable with HIV/AIDs infections, $\mathrm{CO}_{2}$ emissions, and Age above 65 years variables due to multicollinearity problems.

The study findings revealed that the coefficient of ECT was negative and significant, implying model convergence in the long run. This indicated the presence of a long-run relationship among the variables. Any deviations from the long-run equilibrium are corrected at an adjustment speed of $75.7 \%$. A key finding of this study was that the structural break dummy variables were found to have a significant impact on public health expenditure in Kenya. The structural breakpoints for some of the key macroeconomic variables coincided with core economic developments in Kenya. For example, the breakpoint for public health expenditure in 1998 coincided with the post-election political violence that arose from the 1997 General Elections. The breakpoint for GDP per capita in 1991 coincided with the pinnacle point in the struggle for MultiParty Rule (political instability). The year 2003 marked the ushering in of a new government administration that rapidly implemented positive political and governance reforms that, consequently, saw a sharply increased budgetary allocation to the Ministry of Health.

More importantly, the breakpoint in 2013 coincided with the sharp rise in health expenditure due to the counties' devolution effect (implementation of the new constitution). Testing for structural breaks is, thus, very vital when modeling healthcare expenditure models as it yields a more accurate forecast in time-series analysis when compared to those studies that ignore the structural breaks. Furthermore, with the break dummies, the model is a good fit, i.e., it has a higher coefficient of determination. Surprisingly, previous studies on healthcare expenditure in the Kenyan context have, however, failed to take cognizance of this vital inclusion when modeling healthcare expenditure models. 
A $1 \%$ increase in GDP per capita significantly increased public health expenditure by $5.55 \%$ ceteris paribus. This impact was, however, found to be significantly negative in the short run. GDP per capita is a measure of a country's living standard, and it positively informs health expenditure patterns with the impact being heavily felt in the long run (Boachie et al., 2014). A $1 \%$ increase in the number of persons infected with HIV/AIDs significantly increased public health expenditure by $5.14 \%$ ceteris paribus. The impact was, however, found to be insignificant in the short run. HIV/AIDs increases public health expenditure both directly through the acquisition of drugs, i.e., Antiretroviral (ARVs), and indirectly through causing other unforeseen illnesses/ailments. This disease acts as a health shock, thus, causing an upward surge in health expenditure. As observed by Bonfrer and Gustaffson (2016), injury and illness shocks pose a significant risk to households as they result in calamitous health expenditures. Population growth rate and $\mathrm{CO}_{2}$ emissions were found to significantly and positively determine public health expenditure in the short run. This impact was, however, insignificant in the long run.

\section{Conclusions and Policy Implications}

This study found the presence of a long-run relationship between public health expenditure and its determinants in Kenya. Population growth rate and $\mathrm{CO}_{2}$ emissions (proxy to respiratory illnesses) were found to significantly and positively determine public health expenditure in the short run. The impact was, however, found to be insignificant in the long run. Similarly, GDP per capita and the number of HIV/AIDs infections positively and significantly determined public health expenditure in the long run. A key finding of this study highlighted the importance of testing for structural breaks in analyzing a time-series health care expenditure model. Previously, this is something that has been largely omitted in the Kenyan health care context. The structural break dummy variables significantly determined public health expenditure and, therefore, their incorporation in the model yielded a more accurate forecast with better econometric estimates.

Since an increase in public health expenditure is normally occasioned with improved health outcomes, there is a need for the Kenyan Government to increase its budgetary allocation to the Ministry of Health. This will help in achieving the UHC as envisioned in the governments' 'Big Four Agenda' priorities. Furthermore, this will help boost both the human and physical capital which are requisites to facilitating better health care. Besides, there is a need for the Government through the Ministry of Health to develop extensive and effective health shock mitigation strategies to help counter the calamitous health expenditures that are brought about by diseases such as HIV/AIDs pandemic. Pollution control strategies are also paramount in helping to alleviate the illnesses associated with $\mathrm{CO}_{2}$ emissions. 


\section{Funding Information}

No funding sources were provided for this paper.

\section{References:}

1. Ang, J. B. (2010). The determinants of health care expenditure in Australia. Applied Economics Letters, 17 (7): 639-644.

2. Atake, E. H. (2018). Health shocks in sub-Saharan Africa: are the poor and uninsured households more vulnerable? Health Economics Review, 8 (1).

3. Baumol, W. J. (1993). Health care, education and the cost disease: a looming crisis for public choice. Public Choice, 77 (1): 17-28.

4. Becker, G. S. (1964). Human capital. A Theoretical and Empirical Analysis, with Special Reference to Education. New York: Columbia University Press.

5. Boachie, M. K., Mensah, I. O., Sobiesuo, P., Immurana, M., Iddrisu, A. A., \& Kyei-Brobbey, I. (2014). Determinants of public health expenditure in Ghana: A cointegration analysis, Journal of Behavioral Economics, Finance, Entrepreneurship, Accounting and Transport, 2 (2): $35-40$.

6. Bonfrer, I., and Gustaffson-Wright, E. (2016). Health shocks, coping strategies and foregone healthcare among agricultural households in Kenya. Global Public Health, 12 (11): 1369-1390.

7. Breusch, T., \& Pagan, A. (1979). A simple test for heteroskedasticity and random coefficient variation. Econometrica, 47 (5): 1287-1294.

8. Breusch, T. S. (1978). Testing for autocorrelation in dynamic linear models. Australian Economic Papers, 17, 334-55.

9. Buigut, S., Remare, E., and Djesika, D. A. (2015). Catastrophic health expenditure and its determinants in Kenya slum communities. International Journal for Equity in Health, 14 (1), 46.

10. Byaro, M., Abel, K., Charles, M., and Patrick, M. (2018). Determinants of Public Health Expenditure Growth in Tanzania: An Application of Bayesian Model. African Journal of Economic Review, $6(1)$.

11. Dickey, D. A., and Fuller, W. (1979). Distribution of the estimators for autoregressive time series with a unit root, Journal of the American Statistical Association, 74(366, Part 1): 427-431.

12. Galarraga, O., Sosa-Rubi, S. G., Salina-Rodrigues, A., and SesmaVasquez, S. (2009). Health insurance for the poor: impact on catastrophic and out-of-pocket health expenditures in Mexico. European Journal of Health Economics, 11 (5): 437-447. 
13. Gbesemete, K. P., and Gerdtham, U. G. (1992). Determinants of health care expenditure in Africa: A Cross-Sectional Study. World Development, 20 (2): 303-308.

14. Glynn, J., Perera, N., and Verma, R. (2007). Unit root tests and structural breaks: A survey with applications. Journal of Quantitative Methods for Economics and Business Administration, 3 (1): 63-79.

15. Godfrey, L. G. (1978). Testing for higher-order serial correlation in regression equations when the regressors include lagged dependent variables. Econometrica, 46 (6): 1303-1310.

16. Grossman, M. (1972). On the concept of health capital and the demand for health. Journal of Political Economy, 80 (2): 223-255.

17. Grossman, M. (2000). The human capital model. In A. J. Culyer and J. P. Newhouse (Eds.), Handbook of Health Economics (pp. 347-408). Amsterdam: Elsevier.

18. Jarque, C. M. and Bera, A. K. (1987). A Test for Normality of Observations and Regression Residuals. International Statistical Review, 55 (2): 163-172

19. Krishna, A. (2006). Pathways out of and into poverty in 36 villages of Andhra Pradesh. India World Development, 34 (2): 271-288.

20. Leive, A., and $\mathrm{Xu}, \mathrm{K}$. (2008). Coping with out-of-pocket health payments: Empirical evidence from 15 African countries. Bulletin of the World Health Organization, 86 (11): 849-856.

21. Mincer, J. (1974). Schooling, Experience, and Earnings. New York: Columbia University Press.

22. Ministry of Health. (2016). Kenya National Health Accounts 2015/16. Nairobi: Ministry of Health.

23. Munge, K., and Briggs, A. H. (2013). The progressivity of health-care financing in Kenya. Health policy and planning, 29 (7): 912-920.

24. Murthy, V. N. R., and Okunade, A. (2009): The core determinants of health expenditure in the African context: Some econometric evidence for policy. Health Policy, 91 (1): 57-62.

25. Ndirangu, L., Garcia, C., and Gitau, C. (2014). Evidence of Structural Breaks in Kenya Macroeconomic Variables. A paper prepared for the 2014 CSAE Conference held on $23^{\text {rd }}$ to $25^{\text {th }}$ March 2014, University of Oxford: CSAE.

26. Newhouse, J. P. (2002). Medical care costs: how much welfare loss? The Journal of Economic Perspectives, 6 (3): 3-21.

27. Pesaran, M. H. (2015). Time series and panel data econometrics. Oxford: Oxford University Press.

28. Pesaran, M. H., Shin, Y., and Smith, R. J. (2001). Bounds testing approaches to the analysis of level relationships. Journal of Applied Econometrics, 16 (3): 289-326. 
29. Pesaran, M. H. and Shin, Y. (1999). An autoregressive distributed lag modeling approach to cointegration analysis. Econometrics and economic theory in the $20^{\text {th }}$ century. The Ragnar Frisch Centennial Symposium: Cambridge University Press.

30. Phillips, P. C. B., and Perron, P. (1988). Testing For Unit Roots in Time Series Regressions. Biometrika, 75 (2): 335-346.

31. Pomp, M., and Vujic, S. (2008). Rising health spending, new medical technology, and the Baumol effect. CPB Discussion Paper Number 115. The Hague: CPB Netherlands Bureau for Economic Policy Analysis.

32. Rahman, T. (2008). Determinants of public health expenditure: some evidence from Indian states. Applied Economics Letters, 15 (11): $853-$ 857.

33. Republic of Kenya (2012). Ministry of Health. Kenya Health Policy 2012-2030. Nairobi: Government Printer.

34. Republic of Kenya (2014). Budget Speech for the financial year 2014/15. Nairobi: Government printer.

35. Republic of Kenya (2015). Budget Speech for the financial year 2015/16. Nairobi: Government printer.

36. Republic of Kenya (2016). Budget Speech for the financial year 2016/17. Nairobi: Government printer.

37. Republic of Kenya (2017). Budget Speech for the financial year 2017/18. Nairobi: Government printer.

38. Republic of Kenya (2017). Economic Survey. Nairobi: Government printer.

39. Republic of Kenya (2017). Kenya National Health Accounts 2015/2016. Nairobi: Government Printer.

40. Republic of Kenya (2018). Budget Speech for the financial year 2018/19. Nairobi: Government printer.

41. The Big Four (2017). The "Big Four"- Immediate priorities and actions. Specific Priorities for the new term. Nairobi: Government Printer.

42. The Dutch Republic (2016). Kenyan Healthcare Sector. Market Study Report: Opportunities for the Dutch Life Sciences \& Health sector. Nairobi: Kenya Healthcare Federation.

43. Tang, C. F. (2010). The determinants of health expenditure in Malaysia: A time series analysis. MPRA Paper No. 24356.

44. Wagstaff, A. (2008). Measuring financial protection in health. Policy Research Working Paper, 4554, Washington D.C.: World Bank.

45. World Bank (2018). UHC service coverage Index, 2017. Retrieved from: https://data.worldbank.org/indicator/SH.UHC.SRVS.CV.XD. 
46. World Bank (2014). World development report 2014: Risk and opportunity - Managing risk for development. Washington, D.C: World Bank.

47. World Economic Forum (2019). The Global Competitiveness Report 2019. Geneva: World Health Organization.

48. World Health Organization (2017). The World Health Report 2017Tracking Universal Health Coverage. Geneva: World Health Organization.

49. World Health Organization (2010). The World Health Report 2010Health systems financing: the path to universal coverage. Geneva: World Health Organization.

50. World Health Organization (2001). The Abuja Declaration: Ten Years On. Retrieved from: https://www.who.int/healthsystems/publications/Abuja10.pdf.

51. Xu, K., Evans, D., Kawabata, K., Zeramdini, R., Klavus, J., and Murray, C. (2003). Household catastrophic health expenditure: A multicountry analysis. The Lancet, 362 (9378): 111-117.

52. Zivot, E., and Andrews, D. (1992). Further evidence of great crash, the oil price shock, and unit root hypothesis. Journal of Business and Economic Statistics, 10 (3): 251-270. 